\title{
Stalking Following the Breakup of Dating Relationships in Adolescence
}

\author{
Jeane Lessinger Borges ${ }^{*}, 1$ \\ Orcid.org/0000-0002-1925-7047 \\ Débora Dalbosco Dell'Aglio ${ }^{1}$
}

Orcid.org/0000-0003-0149-6450

${ }^{1}$ Universidade Federal do Rio Grande do Sul, Porto Alegre - RS, Brazil

\begin{abstract}
This cross-sectional exploratory study investigated the incidence of stalking subsequent to the breakup of a dating or romantic relationship during adolescence. A total of 117 adolescents (62.4\% female), with a mean age of 16.87 years $(S D=1.26)$, were identified as victims of stalking perpetrated by an ex-intimate partner and were compared to a group of non-victims $(n=410)$ matched by age and sex. "Courtship and Approach" was the most prevalent type of stalking. Adolescents stalking victims exhibited significantly higher mean scores for depression, anxiety and stress symptoms than did non-victims; and female victims presented greater symptomatology than did male victims. Multiple regression analysis indicated that suffering physical and verbal/emotional abuse during a dating relationship explains $19.0 \%$ of the variance of becoming a stalking victim subsequent to the breakup of the relationship. These findings emphasize the need for a better understanding of the stalking phenomenon and for public policies aimed at intervention and prevention, given that both victims and perpetrators require psychological assistance in order to break the dating violence cycle.
\end{abstract}

Keywords: Stalking, harassment, dating violence, adolescence.

\section{Stalking na Pós-Ruptura de Relacionamentos Afetivo-Sexuais na Adolescência}

\section{Resumo}

Este estudo transversal e exploratório investigou a presença de stalking, no período pós-ruptura de relacionamentos afetivo-sexuais de adolescentes. Um total de 117 adolescentes foram identificados como vítimas de stalking por parte do ex-parceiro íntimo (62,4\% meninas), com idade média de 16,87 anos $(D P=1.26)$, os quais foram comparados a um grupo de não vítimas $(n=410)$, emparelhado por idade e sexo. O stalking do tipo cortejamento e aproximação foi o mais prevalente. Adolescentes vítimas de stalking apresentaram escores médios significativamente mais altos nos sintomas de depressão, ansiedade

* Mailing address: Rua Ramiro Barcelos, 2600, sala 115, Porto Alegre - RS, Brasil 90035-003. Phone: (051) 99617-8182; Fax: (051) 3308-5473. E-mail: jeanepsico@yahoo.com.br

Apoio financeiro: Esta pesquisa recebeu suporte financeiro do Conselho Nacional de Desenvolvimento Científico e Tecnológico (CNPq - 402666/2016-0) e a primeira autora recebeu bolsa de doutorado pela Coordenação de Aperfeiçoamento de Pessoal de Nível Superior (CAPES). 
e estresse, quando comparados a não vítimas. Por sua vez, vítimas do sexo feminino apresentaram maior sintomatologia do que vítimas do sexo masculino. Uma análise de regressão múltipla indicou que ter sofrido violência física e verbal/emocional ao longo do relacionamento explica $19,0 \%$ da variância de ser vítima de stalking na pós-ruptura. Destaca-se a necessidade de melhor compreensão do fenômeno do stalking, assim como de políticas públicas de intervenção e prevenção, uma vez que tanto vítimas quanto perpetradores necessitam de atendimento psicológico, a fim de romper o ciclo de violência no namoro.

Palavras-chave: Stalking, assédio, violência no namoro, adolescência.

\section{Stalking en el Periodo Post Ruptura de Relacionamientos Afectivos Sexuales en la Adolescencia}

\section{Resumen}

Este estudio transversal y exploratorio investigó la presencia de stalking, en el periodo post ruptura de relacionamientos afectivos sexuales de adolescentes. Un total de 117 adolescentes fueron identificados como víctimas de stalking por parte de la expareja intima (62.4\% niñas), con edad media de 16.87 años $(D E=1.26)$, los cuales fueron comparados a un grupo de no víctimas $(n=410)$, emparejado por edad y sexo. El stalking del tipo cortejo y aproximación fue lo que más prevaleció. Adolescentes víctimas de stalking presentaron scores medios significativamente más altos en los síntomas de depresión, ansiedad y estrés, cuando comparados a no víctimas. No obstante, víctimas del sexo femenino presentaron sintomatología mayor que las víctimas del sexo masculino. Un análisis de regresión múltiple indicó que haber sufrido violencia física y verbal/emocional a lo largo del relacionamiento explica $19.0 \%$ de la variación de ser víctima de stalking en la post ruptura. Se destaca la necesidad de mejor comprensión del fenómeno del stalking, así como de politicas públicas de intervención y prevención, una vez que tanto víctimas cuanto perpetradores necesitan de atendimiento psicológico, a fin de romper el ciclo de violencia.

Palabras clave: Stalking, asedio, violencia en el noviazgo, adolescencia.

Brazilian and international studies reveal high rates of dating violence during adolescence (Caridade, 2011; Minayo, Assis, \& Njaine, 2011; Wincentak, Connolly, \& Card, 2017), as well as negative impacts on mental health, especially that of the victims (Bonomi, Anderson, Nemeth, Rivara, \& Buettner, 2013; Goncy, Sullivan, Farrell, Mehari, \& Gathe, 2017). According to data obtained via a meta-analysis of 101 international studies (Wincentak et al., 2017), one out of every five adolescents has been the victim of physical violence, and one out of every ten adolescents has suffered sexual abuse perpetrated by an intimate partner. In Brazil, a multicenter study of 3.205 adolescents between the ages of 15 and 19 years, from 10 major Brazilian cities, revealed that $86.9 \%$ had already been the victim of some form of violence in their dating relationships (Minayo et al., 2011).
Stalking is among the various types of violence that can occur in teen dating relationships (Centers for Disease Control and Prevention [CDC/USA], 1998). Despite the lack of consensus in the literature as to the concept of stalking, most of the authors agree that it encompasses a pattern of behavior involving persistent harassment, pursuit or invasion focused on a single target-person (Owens, 2016; Roberts, 2002). Aggressors adopt a wide variety of behavioral tactics, which can range from persistent post-breakup attempts to approach the victim to extremely serious offenses, including homicide, physical and/or sexual abuse, grave threats, and property damage (Logan \& Walker, 2017; Podaná \& Imríšková, 2016). Such abusive behaviors possess an intentional character on the part of the aggressor and cause a negative emotional impact on the victims (Ferreira \& 
Matos, 2013a; Logan \& Walker, 2017). Stalking is a frequent form of violence in interpersonal relationships, occurring within various contexts. Nonetheless, one observes that its manifestation occurs in a more significant manner within the context of romantic relationships, for the victim and the aggressor share a relationship of intimacy (Ferreira, 2013). Along these lines, the present study seeks to spotlight the occurrence of stalking during the post-breakup period of intimate relationships between Brazilian adolescents, given that such circumstances remain little investigated in the Brazilian literature. The study's objective was to examine, from the victim's perspective, the phenomenon of stalking perpetrated by an ex-boyfriend/ girlfriend during the post-breakup period of a teen dating relationship.

In addition to being typified as a form of intimate violence (Grangeia \& Matos, 2006), stalking behavior can also be characterized as a crime, as is the case in the United States and other English-speaking countries (Mullen, Pathé, \& Purcell, 2001; Owens, 2016). In Brazil, although specific legislation concerning stalking does not exist, the theme has been introduced into the legal field via judicial decisions (Jornal da Ordem dos Advogados do Rio Grande do Sul, 2018; Ministério Público do Distrito Federal e Territórios, 2015). In light of the above, studies concerning this theme within the Brazilian context are justified, as well as a more in-depth discussion about the criteria adopted in the literature.

Stalking encompasses a wide range of behaviors involving harassment and threats, in which an individual repeatedly engages in acts such as following someone, showing up at their home or workplace, harassing them over the phone, writing and sending them letters, and/or destroying or vandalizing their property. It involves the use of verbal or written communication, phone calls or even repetitive visual or physical proximity (e.g., pursuit or monitoring) on two or more occasions (CDC/USA, 1998). Logan and Walker (2017) proposed a multidimensional model based on three main aspects: (1) the stalking behaviors are intentional; (2) they cause the victim reasonable fear, including threats that reduce the victim's sense of safety and cause emotional distress; and (3) they are undesirable to the victim or target-individual, who unsuccessfully attempts to interrupt, resist or flee from such persistent persecution or harassment. With respect to the intentionality of the behaviors, a broad range of invasive and abusive tactics exist, including surveillance of the targeted person, life invasion, intimidation and interference.

Ferreira and Matos (2013a) describe three types of stalking that are associated with the post-breakup period of a romantic relationship: (1) Courtship and Approach, in which the exintimate partner employs strategies involving intrusive communication or persistent contact to express affection or other feelings; (2) Harassment and Invasion, which includes strategies to obtain information about the victim, to invade her/his privacy or individuality, and is thus an aggressive and more incisive form of behavior; and (3) Threats and Violence, which involves actions taken to influence the victim's behavior or cause actual harm (Ferreira \& Matos, 2013a). The present study employed the Stalking Behavior Inventory (Ferreira \& Matos, 2013a), which encompasses three categories of stalking behavior: Courtship and Approach, Harassment and Invasion, and Threats and Violence.

Few studies have investigated stalking during adolescence, although there is an estimate that $16.3 \%$ of women and $20.5 \%$ of men suffer stalking before reaching 18 years of age (CDC/ USA, 2014). A study of Portuguese youths revealed a $39.9 \%$ prevalence of stalking during the course of their lives, with an average duration of six months of exposure to it (Ferreira, 2013). In another study, involving 305 university students from the United Kingdom, 34.4\% of the youths were identified as victims of stalking during the post-breakup period of a romantic relationship (Roberts, 2002). Most victims of stalking during adolescence are women (Ferreira, 2013; Purcell, Moller, Flower, \& Mullen, 2009). Behaviors such as controlling the partner's conduct, making excessive phone calls, sending intrusive electronic messages and dropping in on the 
person (invasive visits) were described as forms of adolescent stalking and were associated with dating violence (Bonomi et al., 2013). Although intimidation/threats and invasive communication were more prevalent in various studies (Fischer et al., 2014; Katz \& Rich, 2015), young American female undergraduates, subsequent to breaking up, were also the victims of physical $(19.2 \%)$ and sexual abuse (29.3\%; Katz \& Rich, 2015). Seen in these terms, the post-breakup period of a dating relationship becomes a risk factor for the occurrence of stalking (Edwards \& Gidycz, 2014; Haugaard \& Seri, 2004), especially when there was violence and excessive jealousy in the relationship (Ferreira \& Matos, 2013b; Roberts, 2002; Shorey, Cornelius, \& Strauss, 2015).

Stalking has been associated with social and psychological harm to its victims (Kuehner, Gass, \& Dressing, 2012; Mullen et al., 2001), taking its toll on their mental health (Ferreira \& Matos, 2013a), for they can suffer feelings of anger, paranoia, depression, post-traumatic stress disorder (PTSD) symptoms, and sleep- and eating-related disorders (Spitzberg \& Cupach, 2007), as well as a negative impact on their professional and academic situations (Banyard et al., 2017). In a review of the literature, Mullen et al. (2001) emphasized that victims of persistent stalking display symptomology similar to that of victims of trauma, including domestic violence. According to a prospective study conducted in the United States (Edwards \& Gidycz, 2014), victimization by stalking was a predictor of PTSD symptoms in young female undergraduates going through the postbreakup phase of a violent relationship. A study of women receiving assistance at a center for female victims of intimate partner violence ( $n=389$, USA) investigated the presence of psychological symptoms in three different groups of victims (moderate physical violence without stalking; severe violence without stalking; and severe violence with stalking). The results indicated that the group of victims of severe violence with stalking exhibited greater symptoms of depression, anxiety and PTSD when compared to the other two groups (Logan, Shannon, Cole, \& Walker, 2006). Thus, prior association of violence with stalking seems to increase the emotional impact on the victims. Similarly, a study of an adult population ( $n$ = 665; Mannheim, Germany) revealed that women exhibited greater depressive symptoms, anxiety, and somatoform symptoms than did men (Kuehner et al., 2012), indicating that the impact of exposure to stalking can be influenced by the victim's sex. Adolescent stalking victims ( $n=1.236$, USA) displayed PTSD symptoms, mood alterations and despair, as well as a high frequency of alcohol use and a higher risk of involvement in abusive relationships (Reidy, Smith-Darden, \& Kernsmith, 2016).

Given that there are few studies concerning stalking in adolescence, the present study's objective was to investigate, from the victim's perspective, the phenomenon of stalking perpetrated by an ex-boyfriend/girlfriend during the post-breakup period of a dating relationship. We sought to describe the profile of stalking victims and examine the characteristics of stalking during adolescence, considering the victim's gender, the presence of emotional consequences and the relationship with dating violence. Accordingly, we tested the following research hypotheses: (1) female adolescents are more frequently characterized as victims than are male adolescents; (2) stalking victims exhibit greater symptomology than non-victims do; and (3) there is a continuum of violence over the course of the dating relationship and the stalking; that is, dating violence is a predictor of the occurrence of stalking.

\section{Method}

\section{Participants}

The present cross-sectional exploratory study enjoyed the participation of 527 adolescents between the ages of 14 and 19 years, who were students at ten public and private high schools in the metropolitan region of Porto Alegre (Rio Grande do Sul, Brazil) and were selected via convenience sampling. One hundred and seventeen of the adolescents in the general sample were classified as stalking victims $(22.2 \%)$ and were compared to a group 
of non-victims $(n=410)$. The inclusion criteria for the stalking group were the following: (a) having gone through the breakup of a teen dating relationship at least one month prior to inclusion; (b) having been the victim of at least two or more stalking incidents perpetrated by an ex-boyfriend/girlfriend; (c) such incidents lasted longer than two weeks; and (d) the victim experienced feelings of fear or emotional distress as a result of the stalking behavior. The inclusion criteria for the comparison group were as follows: (a) being between 14 and 19 years of age; (b) currently having or had a romantic relationship (of the "dating" or "casual sex/ one-night stand" type) during adolescence; and (c) not having suffered any type of stalking subsequent to the breakup of the relationship.

The stalking group consisted of 117 adolescents $(62.4 \%$ girls) with a mean age of 16.91 years $(S D=1.26)$ who were students at public and private high schools in the cities of Novo Hamburgo (50.4\%) and Porto Alegre $(49.6 \%)$, both of which are located in the state of Rio Grande do Sul, Brazil. In relation to the intimate relationships, at that moment in their lives $42.0 \%$ of the adolescents were having "nostrings casual sex with someone" and $42.5 \%$ were dating. The comparison group was made up of 410 adolescents $(59.0 \%)$ with a mean age of 16.66 years $(S D=1.16)$ who were also attending public and private high schools in Novo Hamburgo (50.2\%) and Porto Alegre (49.8\%). There were no significant differences between the groups in relation to age and sex variables.

\section{Instruments}

Stalking. We administered an adapted version of the Stalking Behavior Inventory Version II (Portuguese version by Ferreira \& Matos, 2013a), which assesses the prevalence of stalking behaviors in an adult population subsequent to the breakup of an intimate relationship. The instrument consists of 34 items that are rated according to a Likert scale ranging from 0 (never) to 4 (more than five times), encompassing the following three stalking categories: "Courtship and Approach,"
"Harassment and Invasion" and "Threats and Violence." For use in the present study, a pilot survey of 15 adolescents was conducted; it indicated the need to adapt words used in Portugal that have a different meaning in Brazilian Portuguese: The word "cortejamento" (courting) was substituted by "conquista" (winning over), and the word "caxifo," in Item 19, was removed. Additionally, the expression "via the internet" was added to Item 2, ending up as follows in the Brazilian version: "He/ she sought to obtain information about me from my friends, family and classmates, or via the internet." The items "He/she addressed me directly" and "He/she expressed affection for me indirectly" were removed because, during the pilot study, we observed difficulties on the part of the adolescents to understand these phrases. The items "He/she messed with my cell phone, without permission, to look at my messages" and "He/she invaded my profile on social networking websites (Facebook or others)" were also added, given that the adolescents had frequently reported such behaviors. Such changes were made to the above items in an attempt to become more familiar with the slang and circumstances that are most typical of contemporary adolescence. The second part of the inventory consists of 12 items that assess the sociodemographic data of the victim and the perpetrator, data concerning the dating relationship, and the occurrence of violence during the relationship and of stalking perpetrated by the ex-boyfriend/girlfriend. In the present study, the subscales exhibited satisfactory internal consistency, which was assessed via Cronbach's alpha: 0.78 for "Courtship and Approach"; 0.83 for "Harassment and Invasion"; and 0.79 for "Threats and Violence." Additionally, the following criteria were employed: The stalking behaviors must have lasted for more than two weeks (Mullen et al., 2001) and must have occurred on two or more occasions (CDC/USA, 1998).

Teen Dating Violence. We employed the Conflict in Adolescent Dating Relationships Inventory (CADRI; Wolfe, Scott, Reitzel-Jaffe, \& Wekerle, 2001; adapted for Brazil by Minayo et al., 2011), which assesses the presence of 
abusive behaviors in teen dating relationships. The instrument is responded to on a six-point Likert scale, focusing on the following categories of teen dating violence: Physical Violence, Verbal/Emotional Violence, Psychological Violence/Threats, Relational Violence and Sexual Violence. In a study employing the version adapted for Brazil (Minayo et al., 2011), the alpha for violence suffered was 0.87 and for violence perpetrated was 0.88 . In the present study, the Cronbach's alphas were 0.90 for violence suffered and 0.87 for violence perpetrated.

Depression, Anxiety and Stress Symptoms. In order to assess these symptoms, we employed the Depression, Anxiety and Stress Scale for Adolescents (EDAE-A, abbreviation in Portuguese; Patias, Machado, Bandeira, \& Dell'Aglio, 2016), which consists of 21 items that evaluate the presence of depression, anxiety and stress symptoms in the last week. The symptoms are rated on a 3-point Likert scale, with a maximum score of 63 points. The instrument displayed good internal consistency in the validation study for Brazilian adolescents (Patias et al., 2016) between 12 and 18 years of age, with alphas ranging from 0.83 to 0.90 . In the present study, the Cronbach's alphas for the subscales were 0.88 for depression, 0.81 for anxiety and 0.86 for stress.

\section{Data Collection Procedures}

The participants were recruited via convenience sampling at 10 high schools in the metropolitan region of the city of Porto Alegre (state of Rio Grande do Sul, Brazil). We requested authorization from the State Board of Education and from the schools' administrations to conduct the research. Initially, the schools' administrations designated the classes and hours for administering the survey. Next, the researchers held an introductory session to establish rapport with the adolescents, explaining the study's objectives, informing the adolescents as to the voluntariness of their participation and inviting them to voluntarily participate in the survey. After receiving authorization from the parents and from the adolescents themselves, data collection was conducted collectively on the premises of the selected schools during normal classroom hours.

Specifically in relation to the postrelationship stalking survey, the research team held a specific familiarization meeting, informing the adolescents as to the definition of post-breakup stalking and requesting that only those adolescents who met the inclusion criteria defined for this survey answer the stalking questionnaire. This particular survey is part of a larger survey in which the adolescents initially answered questions about romantic relationships, violence in the family of origin and dating violence. The stalking questionnaire was the last one to be completed, as the adolescents that did not meet the inclusion criteria did not fill out this part of the general survey.

\section{Data Analysis Procedures}

Initially, we checked the normality of the variables under study by way of the skewness and kurtosis values and via the Kolgomorov-Smirnov test, all of which indicated that the stalking scores did not display a normal distribution. We also observed a non-normal distribution in relation to the scores of the CADRI and EDAE-A. Accordingly, nonparametric statistics was employed to check the difference in the total scores for stalking and its subscales, as well as in the total scores for the EDAE-A and its subscales, by group (with and without stalking) and by sex, via the Mann-Whitney test. We also calculated the effect size based on the z-score of the Mann-Whitney test, employing the effectsize classification proposed by Cohen (1988): 0.20 to $0.40=$ small effect size; 0.50 to $0.70=$ medium effect; and above $0.80=$ large effect.

Descriptive analyses of the stalking and comparison groups, of the victims' socio-demographic variables and of the dating relationship (type, duration and end) were performed. Simple frequency analyses of the types of stalking behavior were also performed, considering those with an occurrence frequency greater than "more than five times." A chi-square calculation was made in order check the association between being a stalking victim and the victim's sex. In order to calculate the frequency in relation to 
the duration of exposure to stalking, the original scores of the five-point Likert scale were transformed, forming two groups: (1) up to six months of persecution/harassment; and (2) over six months of persecution/harassment.

Lastly, we tested the hypothesis that dating violence is a predictor of post-relationship stalking. Accordingly, four Multiple Linear Regression analyses (stepwise method) were performed independently, whereby the dependent variables were the scores of the stalking subscales and the total score, and the independent variables were the circumstances of having been the victim of physical violence and of having been the victim of verbal/emotional violence during the course of the dating relationship (CADRI). Stepwise estimation was adopted with the aim of checking each independent variable's contribution to the regression model (Hair, Black, Babin, Anderson \& Tatham, 2009). In order to assess multicollinearity, we employed the variance inflation factors (VFIs) and tolerance index, revealing that these prerequisites had been met.

\section{Ethical Procedures}

This study was approved by the Psychology Ethics Committee of the Universidade Federal do Rio Grande do Sul (reference number 1.143.563 of July 6,2015). An informed consent form was requested (for the parents of adolescents under the age of 18 and for participants over 18). The adolescents also signed a consent form to participate in the survey. During the course of data collection, two participants who exhibited discomfort while answering the instruments received special care at the school itself, and were later sent to a women's protection services center for psychological assistance.

\section{Results}

\section{Profile of the Victims}

One hundred and seventeen $(22.2 \%)$ of the adolescents participating in the survey were identified as stalking victims, 73 of whom were female, and 44 were male. With respect to the intimate relationships that had broken up, $70.9 \%$ were dating relationships and $24.8 \%$ were "casual sex" relationships. Most of the cases were heterosexual relationships $(94.8 \%)$, with an average duration of 10.38 months $(S D=10.47)$, ranging between one month and four years. The mean age of the victims at the time of breaking up was 15.80 years $(S D=1.42)$. Regarding the family context, $44.4 \%$ of the stalking victims came from nuclear families, while $21.4 \%$ came from single-parent families; $58.1 \%$ of the victims reported having witnessed some form of conjugal violence on the part of their parents, especially verbal violence ( $53.5 \%$ ); and in $22.2 \%$ of the cases, some form of domestic violence had been reported to the appropriate authorities (guardianship council or police department).

\section{Characterization of Stalking Victimization Patterns}

The results reveal that $100 \%$ of the victims reported having suffered stalking involving Courtship and Approach, 91.5\% related that they had suffered Harassment and Invasion, and $78.6 \%$ mentioned having suffered Threats and Violence. The minimum frequency of stalking subsequent to the breakup of the relationship was three incidents. Adopting the criteria proposed by Mullen et al. (2001) for diagnosing stalking, 101 of the 117 cases identified involved more than ten episodes of stalking during a postbreakup period of over two weeks. Around $49.0 \%$ of the victims reported having received more than five messages from their ex-intimate partner, $15.0 \%$ reported that their ex-partner had kept them under observation or had followed them down the street more than five times, $13.0 \%$ reported that they had been pursued more than five times and $15.0 \%$ reported that their expartner had grabbed them or had impeded them from walking down the street more than three times.

Regarding the duration of the stalking behavior, in most of the cases $(74.0 \%)$ such behavior lasted for a period of up to six months subsequent to the breakup of the relationship, whereas it lasted longer than six months in $26.0 \%$ of the cases, $14.0 \%$ of which lasted longer than one year subsequent to the breakup of the 
relationship, which most clearly demonstrates the persistence of the stalking behavior.

Hypothesis 1: Adolescents of the Female Sex are Frequently Characterized as Victims when Compared to Male Adolescents. Table 1 displays the results, by sex, of the instrument that assesses stalking. There was no significant difference between the sexes in the mean score for stalking or its subscales, although female adolescents did score higher in the "Harassment and Invasion" and "Threats and Violence" subscales and in the total score. Girls reported having been threatened more frequently, for example, in relation to the following items: "He/ she verbally threatened me as to what could happen to me" (81.8\% female victims, $18.2 \%$ male victims) and "He/she threatened to harm himself/herself" (68.4\% girls, $31.6 \%$ boys). Girls also reported greater harassment on social networking websites: "He/she invaded my profile on a social network - Facebook or other" (57.1\% girls, $42.9 \%$ boys). Meanwhile, boys reported having been victims of harassment via phone calls and text messages: "He/she sent or left messages" (54.5\% boys, $46.6 \%$ girls) and "He/she made my phone ring or phoned and hung up without saying anything" (57.1\% boys; $42.9 \%$ girls). In general, chi-squared did not indicate a correlation between different types of stalking and the victim's sex, with the exception of the item "He/she pursued me," which was associated with the female sex $(\chi 2=10.015$, $d f=1, p=.04 ; 86.7 \%$ girls versus $13.3 \%$ boys). Thus, Hypothesis 1 was not confirmed.

Table 1

Means and Standard Deviations on the Stalking Behavior Inventory among Victims by Sex (n=117)

\begin{tabular}{lccccccc}
\hline & $\begin{array}{c}\text { Female }(n=73) \\
M(S D)\end{array}$ & IC 95\% & $\begin{array}{c}\text { Male }(n=44) \\
M(S D)\end{array}$ & IC 95\% & $U$ & $p$ & $d$ \\
\hline Courtship and Approach & $12.37(6.63)$ & $10.82-13.93$ & $13.89(7.67)$ & $11.55-16.22$ & 14.40 & 0.351 & 0.22 \\
Harassment and Invasion & $10.30(8.50)$ & $8.32-12.28$ & $8.93(8.74)$ & $6.27-11.59$ & 13.92 & 0.229 & 0.28 \\
Threats and Violence & $6.51(6.20)$ & $5.06-7.96$ & $5.50(6.50)$ & $3.48-7.52$ & 13.83 & 0.207 & 0.30 \\
Total stalking score & $29.18(18.21)$ & $24.93-33.43$ & $28.32(19.70)$ & $22.33-34.30$ & 15.21 & 0.632 & 0.11 \\
\hline
\end{tabular}

Note. $M=$ median; $S D=$ standard desviations; IC $95 \%=$ confidence interval; $U=$ Mann-Whitney test; $p=$ significance level; $d=$ effect size ( Cohen's $d$ ).

\section{Hypothesis 2: Stalking Victims Exhibit} Greater Symptomology than do Non-Victims. Table 2 displays the stalking and comparison groups' results for the depression, anxiety and stress variables (EDAE-A). A significant difference between the groups was observed in the three subscales and in the total score, with higher mean scores in the stalking group, exhibiting a medium effect size for depression and stress and a large effect size for anxiety and for the total score.

Table 3 displays the scores for the EDAEA's subscales and the total score, by sex. One observes differences in the depression and stress symptoms and in the total EDAE-A score in the stalking victims, with female teenagers exhibiting greater depressive symptoms and higher scores for stress symptoms than those of male adolescents. The results for the total EDAE-A score are in the same direction, thus confirming Hypothesis 2. The effect sizes for these variables are moderate for both the stress score and the total EDAE-A score; and small, for the depression score.

Hypothesis 3: Dating Violence is a Predictor of Stalking. The data indicates that in $32.5 \%$ of the cases some form of violence was present during the breakup period of the dating relationship, with most of the violence being psychological $(55.6 \%)$, followed by physical violence $(25.4 \%)$. Hence, there appears to be a continuum of violence in the stalking cases, in which such violence is not manifested in an isolated manner, thus confirming Hypothesis 3. 
Table 2

Means and Standard Deviations on the EDAE-A among Stalking Victims and Non-Victims $(n=527)$

\begin{tabular}{lccccccc}
\hline & \multicolumn{2}{c}{$\begin{array}{c}\text { Stalking group } \\
(n=117)\end{array}$} & $\begin{array}{c}\text { Comparison group } \\
(n=410)\end{array}$ & $U$ & $p$ & $d$ \\
\cline { 2 - 8 } & $M(S D)$ & IC 95\% & $M(S D)$ & IC 95\% & & \\
\hline Depression EDAE-A & $6.01(5.06)$ & $5.09-6.94$ & $4.58(4.94)$ & $4.07-5.03$ & 19.32 & 0.001 & 0.63 \\
Anxiety EDAE-A & $5.03(4.21)$ & $4.24-5.78$ & $3.09(4.00)$ & $2.70-3.47$ & 15.54 & 0.001 & 1.30 \\
Stress EDAE-A & $8.25(5.33)$ & $7.26-9.22$ & $6.05(5.18)$ & $5.52-6.52$ & 17.73 & 0.001 & 0.87 \\
Total EDAE-A score & $19.26(12.67)$ & $16.94-21.59$ & $13.73(12.58)$ & $12.45-14.88$ & 16.64 & 0.001 & 1.06
\end{tabular}

Note. EDAE-A= Depression, Anxiety and Stress Scale for Adolescents; $\mathrm{M}=$ median; $S D=$ standard desviations; IC $95 \%=$ confidence interval; $U=$ Mann-Whitney test; $p=$ significance level; $d=$ effect size ( Cohen's $d$ ).

Table 3

Means and Standard Deviations on the EDAE-A among Stalking Victims by Sex $(n=117)$

\begin{tabular}{lccccccc}
\hline & $\begin{array}{c}\text { Female } \\
(n=73)\end{array}$ & IC 95\% & $\begin{array}{c}\text { Male } \\
(n=44)\end{array}$ & IC 95\% & $U$ & $P$ & $d$ \\
\cline { 2 - 8 } & $M(S D)$ & & $M(S D)$ & & & \\
\hline Depression EDAE-A & $6.62(5.03)$ & $5.44-7.79$ & $5.00(5.01)$ & $3.48-6.52$ & 12.70 & 0.05 & 0.45 \\
Anxiety EDAE-A & $5.32(4.46)$ & $4.28-6.35$ & $4.57(3.78)$ & $3.42-5.72$ & 14.50 & 0.545 & 0.14 \\
Stress EDAE-A & $9.33(5.26)$ & $8.10-10.56$ & $6.45(5.00)$ & $4.94-7.97$ & 10.74 & 0.003 & 0.75 \\
Total EDAE-A score & $21.26(12.31)$ & $18.39-24.13$ & $16.02(12.78)$ & $12.15-19.89$ & 11.34 & 0.008 & 0.65 \\
\hline
\end{tabular}

Note. EDAE-A= Depression, Anxiety and Stress Scale for Adolescents; $M=$ median; $S D=$ standard desviations; IC $95 \%=$ confidence interval; $U=$ Mann-Whitney test; $p=$ significance level; $d=$ effect size ( Cohen's $d$ ).

Table 4

Multiple Linear Regression Model Predicting Stalking Following Breakup of Dating Relationships $(n=117)$

\begin{tabular}{|c|c|c|c|c|c|c|}
\hline Variables & $\mathrm{B}$ & IC $95 \%$ for $B$ & SE B & $\beta$ & $\mathrm{t}$ & $\mathrm{R}^{2}$ \\
\hline Total Stalking & & & & & & 0.19 \\
\hline Physical Violence CADRI & 2.51 & $0.62-4.40$ & 0.95 & 0.26 & $2.63 * *$ & \\
\hline Verbal/Emotional Violence CADRI & 0.78 & $0.15-1.20$ & 0.26 & 0.25 & $2.56^{* *}$ & \\
\hline Courtship \& approach & & & & & & 0.07 \\
\hline Physical Violence CADRI & 0.98 & $0.33-1.63$ & 0.34 & 0.27 & $3.00 * *$ & \\
\hline Harassment \& Invasion & & & & & & 0.12 \\
\hline Verbal/Emotional Violence CADRI & 0.43 & $0.22-0.64$ & 0.11 & 0.35 & $3.99^{*}$ & \\
\hline Threats \& Violence & & & & & & 0.25 \\
\hline Physical Violence CADRI & 1.10 & $0.48-1.72$ & 0.31 & 0.33 & $3.53 *$ & \\
\hline Verbal/Emotional Violence CADRI & 0.23 & $0.06-0.40$ & 0.08 & 0.25 & $2.67 * *$ & \\
\hline
\end{tabular}

Note. CADRI $=$ Conflict in Adolescent Dating Relationships Inventory.

${ }^{*} p<.001 ; * * p<.05$. 
Multiple regression analysis was employed to test whether exposure to violence (physical CADRI and verbal/emotional CADRI) during the dating relationship predicts greater stalking victimization during the post-breakup period (see Table 4). The results indicate that suffering physical and verbal/emotional violence during the relationship explains $19.0 \%$ of the variance in the total score for post-breakup stalking victimization $[F(2,115)=14.24, p<.001]$. In relation to the Courtship and Approach subscale, previous physical violence explains $0.7 \%$ of the variance of this type of stalking during post-breakup $[F(2,115)=8.97, p$ $<.05]$. Regarding the Harassment and Invasion subscale, suffering verbal/emotional violence during the relationship explains $12.0 \%$ of the variance of subsequent stalking victimization $[F(1,115)=15.93, p<.001]$. Lastly, with respect to the Threats and Violence subscale, suffering physical and verbal/emotional violence during the relationship explains $25.0 \%$ of the variance of stalking victimization during the post-relationship phase $[F(2,115)=$ 20.44, $p<.001]$.

\section{Discussion}

The present study sought to investigate, from the victims' perspective, the occurrence of stalking perpetrated by an ex-boyfriend/ girlfriend during the post-breakup period of a teen dating relationship. The results indicate that Courtship and Approach was the most frequent type of stalking, bearing in mind that this category includes intrusive, repetitive attempts to communicate and/or make contact. Most of the adolescents suffered stalking via messages sent by their ex-partner and via their ex-partner's attempts to obtain information about them from their friends and family or through the web. The occurrence of intrusive, undesirable behaviors - such as sending letters, notes or emails to the victim - was also found to be common in a study concerning stalking among young Finnish undergraduates (Björklund, Häkkänen-Nyholm, Sheridan, \& Roberts, 2010). Such results are similar to those found in earlier stalking studies involving adolescent and young-undergraduate populations (Bonomi et al., 2013; Fischer et al., 2014; Katz \& Rich, 2015), indicating that invasive communication is a commonly employed form of harassment in this age group.

By and large, most of the adolescent stalking victims in the present study suffered more than ten incidents of harassment during the post-breakup period of a romantic relationship, a frequency that is greater than that of stalking incidents in adults (De Smet, Uzieblo, Loeys, Buysse, \& Onraedt, 2015; Edwards \& Gidycz; 2014). Our results indicate a higher frequency of stalking among female victims than among male victims, although this difference is insignificant. This result is similar to those of earlier studies that indicated that women are frequently the main victims of stalking (CDC/USA, 2014; Ferreira \& Matos, 2013a; Podaná \& Imríšková, 2016; Purcell et al., 2009; Roberts, 2002).

With respect to the results as to the psychological symptoms of depression, anxiety and stress, a significant difference was observed between the groups (victims and non-victims), with higher scores among adolescents that were victims. A large effect size was also observed. Earlier studies had already revealed that adolescent stalking victims exhibit greater psychological symptomology than do nonvictims (Diette, Goldsmith, Hamilton, Darity, \& McFarland, 2014; Reidy et al., 2016). A significant difference between the sexes was also found in the scores for depression and stress and in the total EDAE-A score, indicating that female adolescents exhibited greater symptomology. Adolescent female victims of violence perpetrated by an ex-partner tend to display greater symptoms (including depression, suicidal ideation, anxiety and eating disorders) than do adolescent male victims (Romito, Beltramini, \& Escribà-Agüir, 2013). Meanwhile, in the present study, the female adolescents were exposed to violent situations (including harassment $\&$ invasion and violence $\&$ threats) that were more intrusive than those to which the male adolescents were exposed, which 
could explain the female adolescents' greater psychological symptomology.

The present study's results confirm the fact that stalking during the breakup of a teen dating relationship is preceded by violence during the relationship, indicating that suffering psychological and physical violence during a dating relationship is an important predictor of stalking. A study conducted by Katz and Rich (2015) revealed that physical dating violence is a predictor of stalking and of further exposure to physical violence. Likewise, Shorey et al. (2015) pointed out that both the perpetration of and victimization by stalking, among women, are significantly positively correlated with physical and psychological violence during the relationship. Such data corroborates the affirmation made by Ferreira and Matos (2013a) that there is a continuum of violence between the current stalking and the violence already suffered during the relationship.

\section{Final Considerations}

The present study's results confirm that the post-breakup period of a romantic relationship is a risk factor for stalking victimization in adolescents, especially when there has been prior victimization involving physical and psychological violence during the relationship. In the present study, most of the cases involve female victims exposed to the Courtship and Approach type of stalking for a period of over six months, thus indicating that such intrusive and abusive behaviors do not occur during the initial post-breakup phase alone, that is, during the first two weeks following the breakup of the relationship. Earlier studies have pointed out that women (both adolescents and adults) are the principal victims of stalking and that ex-intimate partners, especially men, are the main perpetrators, suggesting that stalking is a specific form of interpersonal, gender-related violence (CDC/USA, 2014; Ferreira \& Matos, 2013b; Podaná \& Imríšková, 2016).

Exposure to stalking was shown to be associated with symptoms of depression, anxiety and stress, thus demonstrating the impact on the victims' mental health. Accordingly, the results corroborate the correlation between exposure to stalking and poor psychological adjustment (Ferreira \& Matos, 2013a; Logan et al., 2006). Nonetheless, there is debate as to whether the observed symptoms of depression, anxiety and stress can be attributed to the stalking itself or whether they derive from accumulated exposure to violence in adolescents' intimate relationships, given that such violence already existed prior to the breakup. Furthermore, it is worth emphasizing that the teenagers who were stalking victims also described a family context characterized by violent situations and that such domestic violence can also explain the impact on mental health.

Regarding the concept of stalking, there still is no consensus in the literature. Stalking encompasses a wide variety of abusive, intentional and persistent behaviors, which can range from intrusive approaching to homicide. Even so, the perpetrator's persistent, intentional character and the emotional impact on the victim, including the fear response, still are the principal basis of consensus in the literature for defining stalking. One aspect that deserves emphasis is to differentiate stalking from a mere attempt to make up and get back together, which is a common practice among adolescents that are going through the breakup of a romantic relationship. Stalking behaviors involving persecution and harassment override a wide range of occasionally irritating and undesirable behaviors that are part of most people's everyday experience when their relationship has come to an end (Mullen et al., 2001). There is thus a tenuous dividing line between such behaviors and harassment that is legally considered a crime. According to the literature, one criterion for making this differentiation is the presence of persecution or harassment that becomes stressful for the victims, interfering with their daily lives and causing them fear (Logan \& Walker, 2017). The results of this study can contribute to making such a distinction in two aspects: (1) the attempts to communicate and get back together are undesirable and they extend for a period of up to six months, 
which would hardly be tolerable in a so-called expected reconciliation process; and (2) such exposure leads to psychological maladjustment, including symptoms of depression, anxiety and stress, especially in adolescent female victims. Furthermore, in addition to following fixed criteria, as was proposed by Mullen et al. (2001), including the occurrence of ten or more abusive behaviors during a period of over two weeks or the presence of the emotional fear response, which has already been discussed in the present study, we also recommend assessing each case individually. Such an assessment should evaluate the risks, severity and frequency of the acts perpetrated and their impact on the targeted individual's mental health so as to ensure the victim's safety and well-being.

The present study has several limitations, including the fact that it is across-sectional exploratory study featuring data that was obtained from the self-report of only one respondent in each dyadic relationship, most of which were heterosexual relationships. Accordingly, future studies should focus on stalking that occurs in relationships between people of the same sex, as well as seeking to comprehend the stalking phenomenon by way of information provided by couples that have already separated. Furthermore, this study did not examine the profile of stalking perpetrators, which would be interesting in order to better understand their invasive behaviors. Despite such limitations, this study is nonetheless a pioneering, innovative study in Brazil, seeking to make advances in the area of teen dating violence, given that, in general, Brazilian studies have focused on physical and psychological violence in adolescent dating relationships. Moreover, it is worth emphasizing that most studies concerning stalking involve adult populations.

The results of this study can contribute to the development of public policies aimed at interventions and the prevention of stalking. It is noteworthy that adolescents tend to experience difficulty in relation to recognizing signs of violence in their dating relationships and seeking help and support in such situations (Soares, Lopes, \& Njaine, 2013). Stalking prevention models include conflict-resolution skills training and psychoeducation, and they view adolescents as disseminators in their respective communities (CDC/USA, 2017).Finally, we recommend conducting further studies within the Brazilian context in order to give the phenomenon greater exposure and to seek to understand the manner in which sociocultural factors can influence stalking patterns during adolescence.

\section{References}

Banyard, V. L., Demers, J. M., Cohn, E. S., Edwards, K. M., Moynihan, M. M., Walsh, W. A., \& Ward, S. K. (2017). Academic correlates of unwanted sexual contact, intercourse, stalking, and intimate partner violence: An understudied but important consequence for college students. Journal of Interpersonal Violence. Advance online publication. doi: 10.1177/0886260517715022

Björklund, K., Häkkänen-Nyholm, H., Sheridan, L., \& Roberts, K. (2010). The prevalence of stalking among Finnish university students. Journal of Interpersonal Violence, 25(4), 684-698. doi: $10.1177 / 0886260509334405$

Bonomi, A. E., Anderson, M. L., Nemeth, J., Rivara, F. P., \& Buettner, C. (2013). History of dating violence and the association with late adolescent health. BMC Public Health, 13(821). Retrieved from http://www.biomedcentral.com/1471$2458 / 13 / 821$

Caridade, S. (2011). Vivências intimas violentas: Uma abordagem cientifica. Coimbra, Portugal: Almedina.

Centers for Disease Control and Prevention. (1998). Stalking in America: Findings from the national violence against women survey. Retrieved from https://www.ncjrs.gov/pdffiles/169592.pdf

Centers for Disease Control and Prevention. (2014). Prevalence and characteristics of sexual violence, stalking, and intimate partner violence victimization - National intimate partner and sexual violence survey, United State, 2011. Retrieved from http://www.cdc.gov/mmwr/ preview/mmwrhtml/ss6308a1.htm?s_cid=ss6308a1 w

Centers for Disease Control and Prevention. (2017). Stalking: Know it. Name it. Stop it. Retrieved from https://www.cdc.gov/features/prevent-stalking/index.html 
Cohen, J. (1988). Statistical power analysis for the behavioral sciences (2nd ed.). Hillsdale, NJ: Erlbaum.

De Smet, O., Uzieblo, K., Loeys, T., Buysse, A., \& Onraedt, T. (2015). Unwanted pursuit behavior after breakup: Occurrence, risk factors, and gender differences. Journal of Family Violence, 30, 753-767. doi: 10.1007/s10896-015-9687-9

Diette, T. M., Goldsmith, A. H., Hamilton, D., Darity, W., Jr., \& McFarland, K. (2014). Stalking: Does it leave a psychological footprint? Social Science Quarterly, 95(2), 563-580. doi: 10.1111/ ssqu. 12058

Edwards, K. M., \& Gidycz, C. A. (2014). Stalking and psychosocial distress following the termination of an abusive dating relationship: A prospective analysis. Violence Against Women, 20(11), 1383-1397. doi: 10.1177/1077801214552911

Ferreira, J. P. M. (2013). Stalking como forma de violência nas relações de namoro. Retrieved from http://comum.rcaap.pt/handle/123456789/6243

Ferreira, C., \& Matos, M. (2013a). Violência doméstica e stalking pós-rutura: Dinâmicas, coping e impacto psicossocial na vítima. Psicologia, 27(2), 81-106.

Ferreira, C., \& Matos, M. (2013b). Post-relationship stalking: The experience of victims with and without history of partner abuse. Journal of Family Violence, 28(4), 393-402. doi: 10.1007/ s10896-013-9501-5

Fischer, B. S., Coker, A. L., Garcia, L. S., Williams, C. M., Clear, E. R., \& Cook-Craig, P. G. (2014). Statewide estimates of stalking among high school students in Kentucky: Demographic profile and sex differences. Violence Against Women, 20(10), 1258-1279. doi: $10.1177 / 1077801214551574$

Goncy, E. A., Sullivan, T. N., Farrell, A. D., Mehari, K. R., \& Garthe, R. C. (2017). Identification of patterns of dating aggression and victimization among urban early adolescents and their relations to mental health symptoms. Psychology of Violence, 7(1), 58-68. doi: 10.1037/vio0000039

Grangeia, H., \& Matos, M. (2006). Riscos associados ao stalking: Violência, persistência e reincidência. Psiquiatria, Psicologia \& Justiça, 5, 29-48.

Hair, J. F., Black, W. C., Babin, B. J., Anderson, R. E., \& Tatham, R. L. (2009). Análise multivariada de dados (6th ed.). Porto Alegre, RS: Bookman.
Haugaard, J. J., \& Seri, L. G. (2004). Stalking and others forms of intrusive contact among adolescents and young adults from the perspective of the person initiating the intrusive contact. Criminal Justice and Behavior, 31(1), 37-54. doi: 10.1177/0093854803259247

Jornal da Ordem dos Advogados do Rio Grande do Sul. (2018). Homen é condenado por stalking contra mulher em Foz do Iguaçu. Retrieved from http://jornaldaordem.com.br/noticia-ler/homeme-condenado-por-stalking-contra-mulher-emfoz-iguacu/43658

Katz, J., \& Rich, H. (2015). Partner covictimization and post-breakup stalking, pursuit, and violence: A retrospective study of college women. Journal of Family Violence, 30, 189-199. doi: 10.1007/ s10896-014-9665-7

Kuehner, C., Gass, P., \& Dressing, H. (2012). Mediating effects of stalking victimization on gender differences in mental health. Journal of Interpersonal Violence, 27(2), 199-221. doi: $10.1177 / 0886260511416473$

Logan, T. K., Shannon, L., Cole, J., \& Walker, R. (2006). The impact of differential patterns of physical violence and stalking on mental health and help-seeking among women with protective orders. Violence Against Women, 12(9), 866886. doi: 10.1177/1077801206292679

Logan, T. K., \& Walker, R. (2017). Stalking: A multidimensional framework for assessment and safety planning. Trauma, Violence, \& Abuse, 18(2), 200-222. doi: 10.1177/1524838015603210

Minayo, M. C. S., Assis, S. G., \& Njaine, K. (2011). Amor e violência: Um paradoxo das relações de namoro e do "ficar" entre jovens brasileiros. Rio de Janeiro, RJ: Fundação Oswaldo Cruz.

Ministério Público do Distrito Federal e Territórios. (2015). Homem é condenado por praticar stalking contra a ex-companheira. Retrieved from http://www.mpdft.mp.br/ portal/index.php/comunicacao-menu/noticias/ noticias-2015/noticias-2015-lista/7998-homeme-condenado-por-praticar-stalking-contra-excompanheira

Mullen, P. E., Pathé, M., \& Purcell, R. (2001). Stalking: New constructions of human behavior. Australian and New Zealand of Psychiatry, 35, 9-16.

Owens, J. G. (2016). Why definitions matter: Stalking victimization in the United States. Journal of 
Interpersonal Violence, 31(12), 2196-2226. doi: $10.1177 / 0886260515573577$

Patias, N. D., Machado, W. L., Bandeira, D. R., \& Dell'Aglio, D. D. (2016). Depression Anxiety and Stress Scale (DASS-21) - Short Form: Adaptação e Validação para Adolescentes Brasileiros. Psico-USF, 21(3), 459-469. doi: $10.1590 / 1413-82712016210302$

Podaná, Z., \& Imríšková, R. (2016). Victims' responses to stalking: An examination of fear levels and coping strategies. Journal of Interpersonal Violence, 31(5), 792-809. doi: $10.1177 / 0886260514556764$

Purcell, R., Moller, B., Flower, T., \& Mullen, P. E. (2009). Stalking among juveniles. The British Journal of Psychiatry, 194, 451-455. doi: 10.1192/bjp.bp.108.054833

Reidy, D. E., Smith-Darden, J. P., \& Kernsmith, P. D. (2016). Behavioral and mental health correlates of youth stalking victimization: A latent class approach. American Journal of Preventive Medicine, 51(6),1007-1014. doi: 10.1016/j. amepre.2016.08.035

Roberts, K. A. (2002). Stalking following the breakup of romantic relationships: Characteristics of stalking former partners. Journal of Forensic Science, 47(5). Retrieved from http://www. astm.org/DIGITAL_LIBRARY/JOURNALS/ FORENSIC/PAGES/JFS15514J.htm

Romito, P., Beltramini, L., \& Escribà-Agüir, V. (2013). Intimate partner violence and mental health among Italian adolescents: Gender similarities and differences. Violence Against Women, 19(1), 89-106. doi: 10.1177/1077801212475339
Shorey, R. C., Cornelius, T. L., \& Strauss, C. (2015). Stalking in college student dating relationships: A descriptive investigation. Journal of Family Violence, 30(7), 935-942. doi: 10.1007/s10896015-9717-7

Soares, J. S. F., Lopes, M. J. M., \& Njaine, K. (2013). Violência nos relacionamentos afetivo-sexuais entre adolescentes de Porto Alegre, Rio Grande do Sul, Brasil: Busca de ajuda e rede de apoio. Cadernos de Saúde Pública, 29(6), 1121-1130. doi: 10.1590/S0102-311X2013000600009

Spitzberg, B. H., \& Cupach, W. R. (2007). The state of the art of stalking: Taking stock of the emerging literature. Aggression and Violent Behavior, 12, 64-86. doi: 10.1016/j.avb.2006.05.001

Wincentak, K., Connolly, J., \& Card, N. (2017). Teen dating violence: A meta-analytic review of prevalence rates. Psychology of Violence, 7(2), 224-241. doi: 10.1037/a0040194

Wolfe, D. A., Scott, K., Reitzel-Jaffe, D., \& Wekerle, C. (2001). Development and validation of the conflict in adolescent dating relationships inventory. Psychological Assessment, 13, 277 293. doi:10.1037/1040-3590.13.2.277

(C) The Author(s), 2018. Open Access. This article is distributed under the terms of the Creative Commons Attribution 4.0 International License (http://creativecommons.org/licenses/by/4.0/), which permits unrestricted use, distribution, and reproduction in any medium, provided you give appropriate credit to the original author(s) and the source, provide a link to the Creative Commons license, and indicate if changes were made. 